\title{
THE EFFECTS OF DEHYDRATION ON ELECTROLYTE CONCENTRATIONS IN A TOAD, BUFO MARINUS*
}

\author{
VAUGHAN H. SHOEMAKER \\ Department of Zoology, University of Michigan, Ann Arbor
}

(Received 1 May 1964)

\begin{abstract}
Dehydration of toads with empty bladders causes elevation of the sodium concentration (C) of their plasma according to the relationship:

$$
C=C_{0} \times \frac{\text { original water content }}{\text { original water content }- \text { water deficit }},
$$

where $C_{0}$ is the plasma sodium concentration of the hydrated toad and volumes are expressed as $\mathrm{ml} / 100 \mathrm{~g}$ of hydrated toad.

2. The concentration of potassium in the plasma declines in the initial stages of dehydration and returns to the hydrated level only when the toad has lost $20-30 \mathrm{ml}$ of water $/ 100 \mathrm{~g}$.

3. The sum of the concentrations of sodium and potassium in tissue water is increased in dehydrated toads according to the same relationship found for plasma sodium.

4. Tissues lose a smaller fraction of their water than does the whole toad during dehydration. The retention of water by tissues during dehydration is apparently associated with their uptake of electrolytes.

5. Dilute urine stored in the bladder may be utilized by toads during dehydration in maintaining the sodium concentration of the plasma at the normal level. As water is lost in excess of the volume of urine initially present in the bladder, the plasma sodium concentration increases as described in (1) above.
\end{abstract}

\section{INTRODUCTION}

IN vIEW of the susceptibility of amphibians to evaporative water loss, the exceptional ability of some species to tolerate dehydration is probably of considerable importance in enabling them to exploit terrestrial habitats (Thorson \& Svihla, 1943). However, little is known of the physiological basis for the tolerance of these animals to dehydration, and, in fact, surprisingly little information is available concerning the effects of water loss in vertebrates generally. Experiments described here were undertaken as part of an investigation addressed to this problem.

Concentrations of electrolytes in the body fluids are regulated within narrow limits by vertebrates under favorable conditions. However, water losses might be expected to concentrate the body fluids of amphibians since these animals are unable to excrete urine with a higher osmotic concentration than the plasma.

* Study supported by National Science Foundation Fellowships and National Institutes of Health Traineeship. 
These experiments were designed to determine what, if any, mechanisms for the regulation of ionic concentrations of the body fluids are employed by toads during dehydration.

\section{MATERIALS AND METHODS}

Specimens of Bufo marinus weighing 100-250 g were obtained from commercial suppliers for use in this investigation. They were maintained at $20-25^{\circ} \mathrm{C}$ in pans containing a shallow layer of tap water and were force-fed beef liver and canned dog food once or twice each week. Toads were not fed for 2 weeks preceding an experiment. Prior to dehydration the standard weight (weight of a fully hydrated animal with no urine in its bladder-see Ruibal, 1962) of each toad was determined. Toads were then placed in wire cages in the laboratory. Subsequent weight losses were taken to reflect the evaporation of water, since no urine or feces was voided by the toads under these conditions. Rates of evaporative water loss approximated $1 \mathrm{ml} /(100 \mathrm{~g} \times \mathrm{hr})$.

Small blood samples $(0 \cdot 05-0 \cdot 10 \mathrm{ml})$ were obtained from intact toads by heart puncture with a No. 27 needle attached to a heparinized syringe. Toads subjected to repeated blood sampling showed no apparent ill effects from this treatment. Blood samples were sealed in capillary tubes and centrifuged to provide plasma for analysis. Sodium and potassium determinations were made on plasma and urine samples using a Coleman model 21 flame photometer.

Two procedures were used to determine the effect of dehydration on concentrations of sodium and potassium in plasma of toads having empty bladders at the onset of dehydration. In the first, a blood sample was taken from each of twelve hydrated toads. As dehydration progressed, one to three additional blood samples were taken from each toad. In the second method, which served as a control against the effects of repeated blood sampling during a brief period, blood samples were taken from eight hydrated toads that were then returned to water for 3 days before being dehydrated to about 92 per cent of their hydrated weight. Blood samples were then taken and the toads were returned to water for 2 days, after which blood samples were again obtained. The animals then remained in water for 3 more days before being removed and dehydrated to 80 per cent of their hydrated weight when blood was again sampled.

To determine the effects of dehydration on the water and ionic contents of their tissues, five toads that had been dehydrated to 80 per cent of their standard weight were compared with five hydrated toads. A blood sample was obtained from each toad and the animal was then pithed. The heart, liver, kidneys, lungs and both gastrocnemius muscles were rapidly removed, blotted, placed in tared $10 \mathrm{ml}$ beakers, and weighed to the nearest $\mathrm{mg}$. One of the muscles and about $1 \mathrm{~g}$ of liver were used for ion determinations, whereas the other tissues and the carcass of each toad were dried to constant weight at $105^{\circ} \mathrm{C}$. Muscle and liver samples were prepared for ion analysis by homogenizing each for $10 \mathrm{~min}$. in a Waring blender, using distilled water to bring the total volume of each homogenate to $300 \mathrm{ml}$. The homogenates were transferred to flasks and allowed to stand, with occasional shaking, for $24 \mathrm{hr}$ 
at room temperature. Portions of each supernatant, as well as the plasma samples, were analyzed for sodium and potassium by flame photometry. Chloride concentrations of the muscle homogenates and plasma samples were measured volumetrically by titration with $\mathrm{AgNO}_{3}$ using $\mathrm{K}_{2} \mathrm{CO}_{4}$ as indicator. Chloride determinations were not made on the liver homogenates because their color obscured the end point.

In experiments designed to assess the utilization by toads of urine stored in the bladder prior to dehydration, a glass cannula was inserted into the cloaca of each of five toads and held secure with a purse-string ligature. After the standard weight of the toad was determined, the cannula was closed with a short length of plugged rubber tubing into which a needle could be introduced to obtain urine samples. The animal was then returned to water. Since the standard weight of toads fluctuates very little, their subsequent gains of weight were assumed to represent the accumulation of urine in the bladder. After a previously specified amount of urine had accumulated, small samples of blood and urine were obtained and the toad was placed in a wire cage. Blood and urine samples were taken at various intervals during dehydration. These, along with the initial samples, were analyzed for sodium and potassium. The estimated volume of urine in the bladders of the five toads at the beginning of dehydration ranged from $6-31 \mathrm{ml} / 100 \mathrm{~g}$ standard weight.

\section{RESULTS}

The concentration of sodium in the plasma increases markedly as toads having empty bladders at the onset of water deprivation are dehydrated (Fig. 1). The potassium concentration, on the other hand, drops initially and returns to the hydrated level only after water losses equivalent to 20-30 per cent of the body weight have occurred (Fig. 2). The mean concentration ( \pm S.D.) of sodium in the plasma of the hydrated toads used in the serial sampling experiment was $114.2 \pm 6.8 \mathrm{~m}$-equiv./1. The corresponding value for potassium was $4 \cdot 16 \pm 0.49$ m-equiv./1. Results obtained when toads were kept in water for several days between samplings have been plotted in Figs. 1 and 2 to show their similarity to results obtained by serial sampling. The average of the two hydrated values obtained for each toad was used to calculate the relative changes in concentration shown in these figures.

Water contents of tissues from hydrated toads are compared, in Table 1, with those from toads which had lost $20 \mathrm{ml} / 100 \mathrm{~g}$ through evaporation. Each of the tissues examined lost a significantly smaller fraction of its original water content than did the whole toad $(P<0.05$ Mann-Whitney $U$ test $)$. It is also of interest to note the correlation between the fraction of the original water content lost by a tissue and the amount of water it originally contained. Electrolyte concentrations of muscle and liver samples, determined as m-equiv. $/ \mathrm{kg}$ wet weight, were converted to $\mathrm{m}$-equiv./kg dry weight and m-equiv./1 of tissue water using the ratio of dry weight to wet weight obtained from the other sample of the tissue from the same toad. These values, along with electrolyte concentrations in the plasma, are summarized in Table 2. 
Toads starting with dilute urine in their bladders maintain the concentration of sodium in their plasma at the hydrated level during the initial stages of dehydration (Table 3). Moreover, the amount of evaporation that can occur without

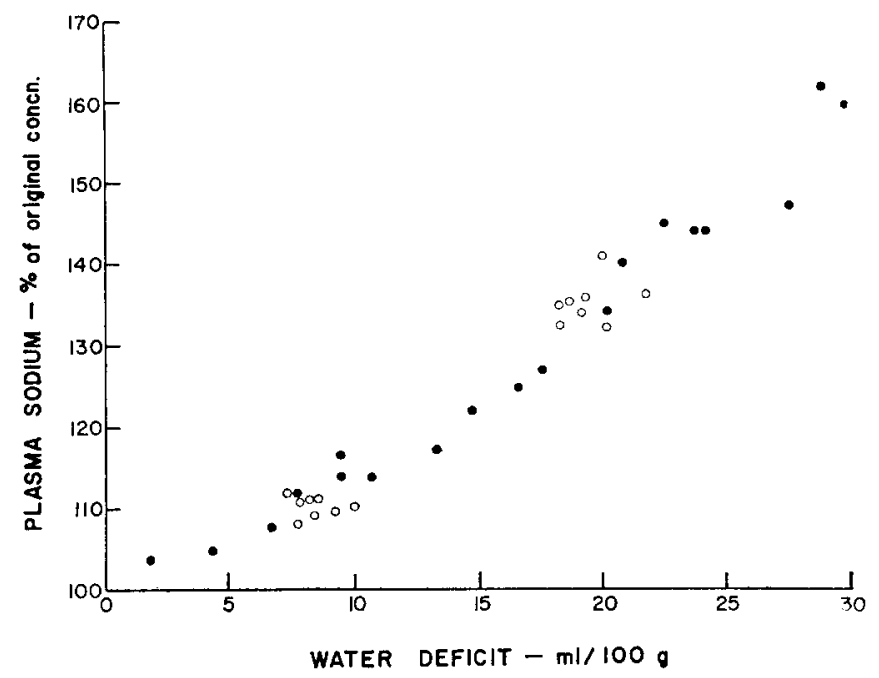

FIG. 1. Effect of dehydration on the sodium concentration of the plasma of Bufo marinus. - data obtained by taking samples serially during dehydration; 0 , toads kept in water several days between dehydrations.

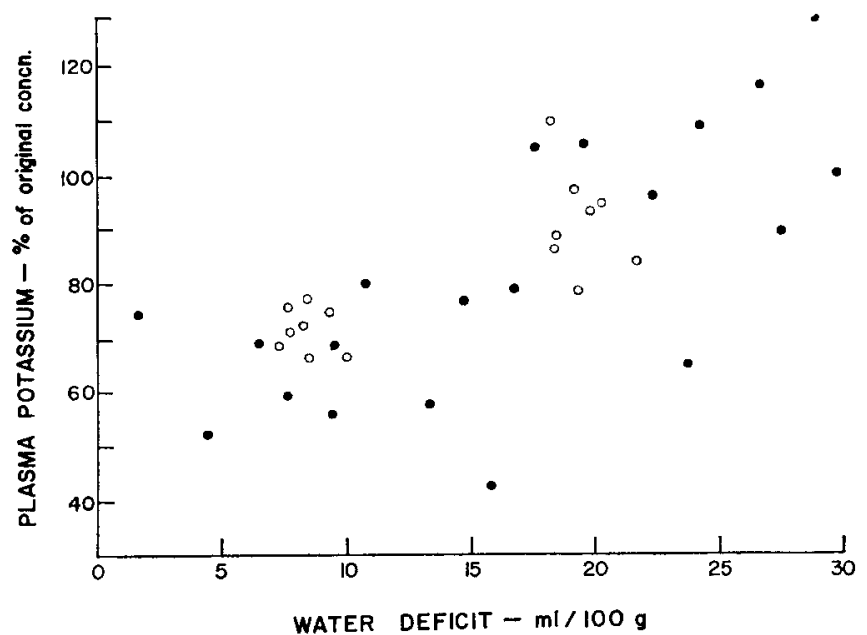

Fig. 2. Effect of dehydration on the potassium concentration of the plasma of Bufo marinus. Symbols as in Fig. 1.

elevation of this concentration varies with the volume of urine initially present in the bladder. The extent of utilization of the stored urine can be estimated more precisely by examining the effect of dehydration on a function of the concentration 
TABLE 1-EFFECT OF DEHYDRATION ON THE WATER CONTENT OF various tissues in Bufo marinus

\begin{tabular}{|c|c|c|c|c|c|c|}
\hline \multirow{3}{*}{ Tissue } & \multicolumn{2}{|c|}{ Hydrated toads } & \multicolumn{2}{|c|}{$\begin{array}{l}\text { Toads dehydrated to } \\
80 \% \text { of original wt. }\end{array}$} & \multirow{3}{*}{$\begin{array}{c}\% \text { of } \\
\text { original } \\
\text { water } \\
\text { content } \\
\text { lost }\end{array}$} & \multirow{3}{*}{$\begin{array}{c}\text { "Excess" } \\
\text { water } \\
\text { retained" } \\
\text { (ml/g dry wt.) }\end{array}$} \\
\hline & ml water & $\mathrm{ml}$ water & ml water & ml water & & \\
\hline & $100 \mathrm{~g}$ wet wt. & g dry wt. & $100 \mathrm{~g}$ wet wt. & g dry wt. & & \\
\hline Liver & $\begin{array}{l}76 \cdot 6 \\
(0 \cdot 56)\end{array}$ & $3 \cdot 27$ & $\begin{array}{l}72 \cdot 9 \\
(0 \cdot 39)\end{array}$ & $2 \cdot 69$ & $17 \cdot 7$ & $0 \cdot 26$ \\
\hline $\begin{array}{l}\text { Skeletal } \\
\text { muscle }\end{array}$ & $\begin{array}{l}81 \cdot 2 \\
(0 \cdot 29)\end{array}$ & $4 \cdot 31$ & $\begin{array}{l}77 \cdot 6 \\
(0 \cdot 26)\end{array}$ & $3 \cdot 47$ & $18 \cdot 5$ & $0 \cdot 27$ \\
\hline Kidney & $\begin{array}{l}83 \cdot 8 \\
(0 \cdot 31)\end{array}$ & $5 \cdot 17$ & $\begin{array}{l}80 \cdot 5 \\
(0 \cdot 63)\end{array}$ & $4 \cdot 13$ & $20 \cdot 3$ & $0 \cdot 27$ \\
\hline Lung & $\begin{array}{l}86 \cdot 0 \\
(0 \cdot 23)\end{array}$ & $6 \cdot 14$ & $\begin{array}{l}83 \cdot 0 \\
(0 \cdot 43)\end{array}$ & $4 \cdot 88$ & $20 \cdot 5$ & $0 \cdot 31$ \\
\hline Heart & $\begin{array}{l}86 \cdot 1 \\
(0 \cdot 27)\end{array}$ & $6 \cdot 19$ & $\begin{array}{l}82 \cdot 8 \\
(0 \cdot 47)\end{array}$ & $4 \cdot 81$ & $22 \cdot 3$ & $0 \cdot 21$ \\
\hline Whole toad & $\begin{array}{l}78 \cdot 0 \\
(0 \cdot 43)\end{array}$ & $3 \cdot 55$ & $\begin{array}{l}72 \cdot 5 \\
(0 \cdot 63)\end{array}$ & $2 \cdot 64$ & $25 \cdot 6$ & \\
\hline
\end{tabular}

Values shown are means for five toads; standard errors of means in parentheses.

* Water retained in excess of that which would have remained had the tissue lost the same fraction of its water content as the whole toad.

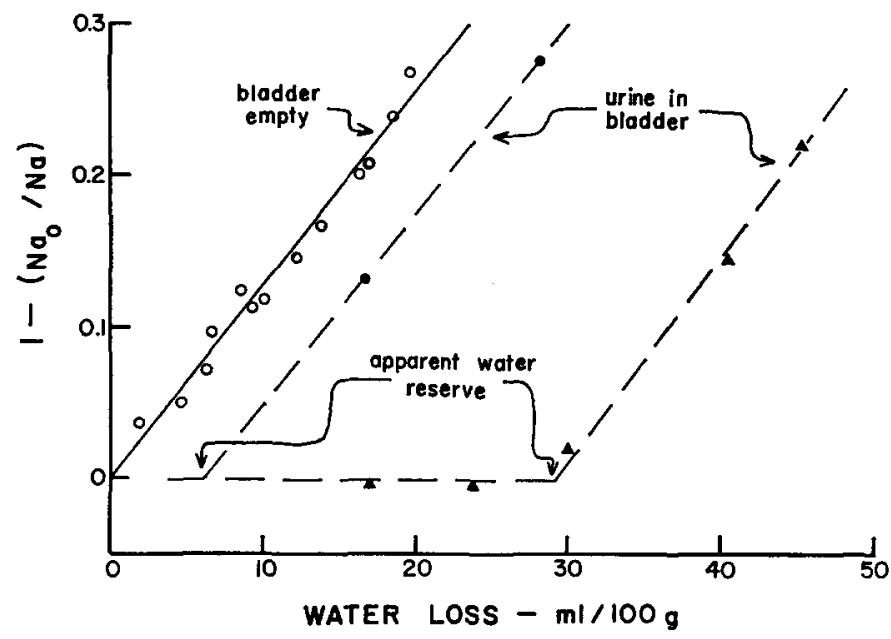

FIG. 3. Effect of dehydration on a function of the concentration of sodium in the plasma, $1-\left(\mathrm{Na}_{0} / \mathrm{Na}\right)$, in Bufo marinus. $\mathbf{N a}_{0}=$ the original sodium concentration; $\mathrm{Na}=$ the concentration of sodium in the plasma after the toad has become dehydrated. $O$, toads with empty bladders at the onset of dehydration; $\bullet$, toad No. $8 ; \Delta$, toad No. 3 . 


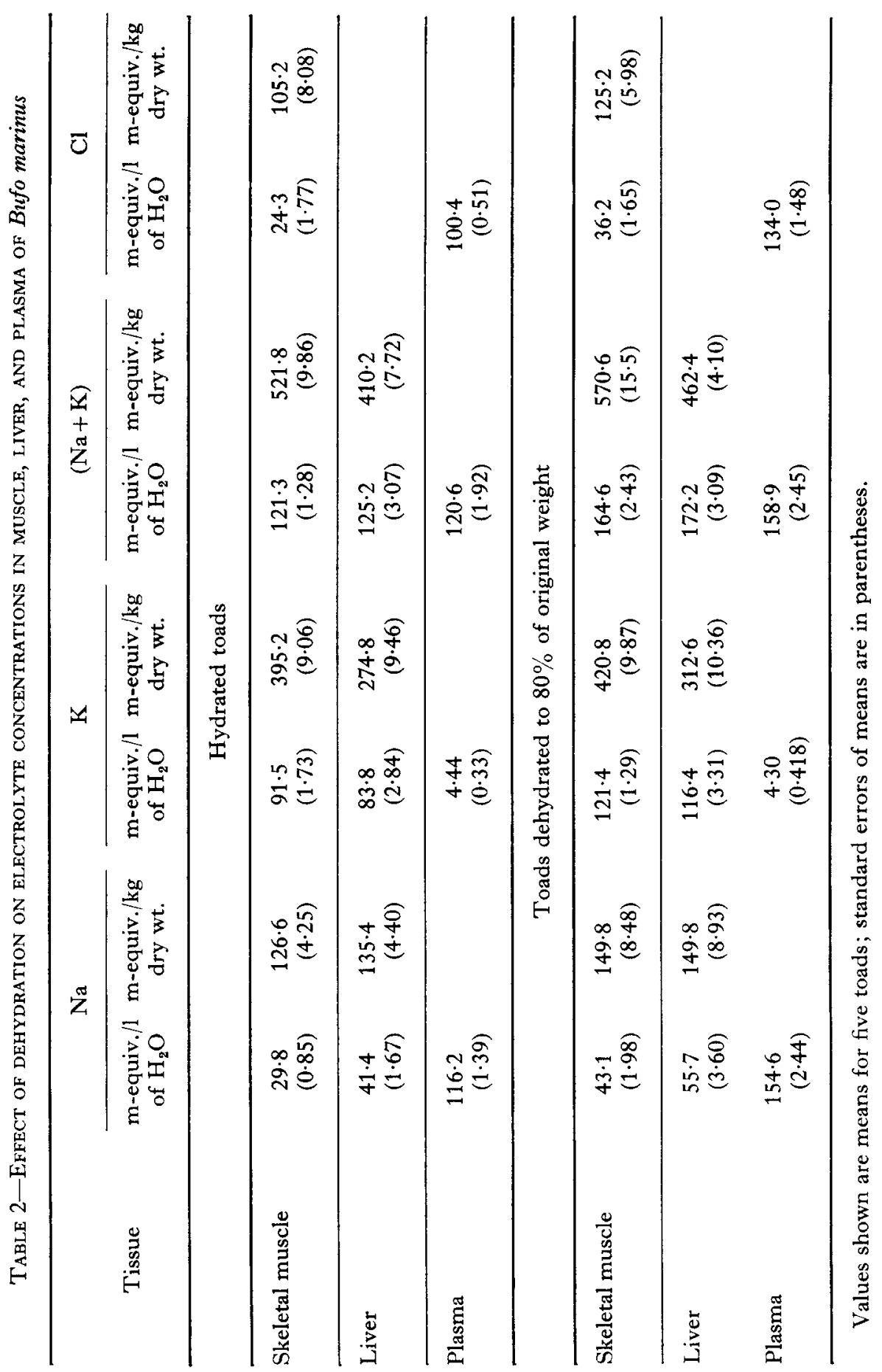


of sodium in the plasma, as in Fig. 3. A straight line through the origin is described by data obtained from toads having empty bladders at the start of dehydration (see Discussion). In toads starting with urine in their bladders, the concentration of sodium in the plasma does not change appreciably until the available water

TABLE 3-EFFECT OF WATER LOSS ON THE SODIUM AND POTASSIUM CONCENTRATIONS IN PLASMA AND URINE OF Bufo marinus HAVING URINE IN THE BLADDER AT THE ONSET OF DEHYDRATION

\begin{tabular}{|c|c|c|c|c|c|c|}
\hline \multirow{2}{*}{$\begin{array}{l}\text { Toad } \\
\text { No. }\end{array}$} & \multirow{2}{*}{$\begin{array}{l}\text { Estimated bladder } \\
\text { reserve }(\mathrm{ml} / 100 \mathrm{~g})\end{array}$} & \multirow{2}{*}{$\begin{array}{c}\text { Evaporative } \\
\text { water loss } \\
(\mathrm{ml} / 100 \mathrm{~g})\end{array}$} & \multicolumn{2}{|c|}{$\begin{array}{l}\text { Plasma concn. } \\
\text { (m-equiv./1) }\end{array}$} & \multicolumn{2}{|c|}{$\begin{array}{l}\text { Urine concn. } \\
\text { (m-equiv./1) }\end{array}$} \\
\hline & & & $\mathrm{Na}$ & $\mathbf{K}$ & $\mathrm{Na}$ & $\mathrm{K}$ \\
\hline 8 & $6 \cdot 0$ & $\begin{array}{r}0 \cdot 0 \\
16 \cdot 6 \\
27 \cdot 8\end{array}$ & $\begin{array}{l}128 \\
148 \\
177\end{array}$ & $\begin{array}{l}3 \cdot 5 \\
4 \cdot 0 \\
3 \cdot 4\end{array}$ & $5 \cdot 7$ & 0.9 \\
\hline 27 & $11 \cdot 5$ & $\begin{array}{r}0 \cdot 0 \\
5 \cdot 7 \\
13 \cdot 3 \\
34 \cdot 6\end{array}$ & $\begin{array}{r}88 \\
87 \\
88 \\
122\end{array}$ & $\begin{array}{l}3.9 \\
3 \cdot 6 \\
3 \cdot 0\end{array}$ & $\begin{array}{l}6 \cdot 0 \\
6 \cdot 2\end{array}$ & $\begin{array}{l}1 \cdot 0 \\
2 \cdot 2\end{array}$ \\
\hline 28 & $21 \cdot 0$ & $\begin{array}{r}0 \cdot 0 \\
6 \cdot 7 \\
15 \cdot 7 \\
23 \cdot 2 \\
44 \cdot 8\end{array}$ & $\begin{array}{l}104 \\
101 \\
101 \\
107 \\
139\end{array}$ & $\begin{array}{l}2 \cdot 8 \\
2 \cdot 3 \\
2 \cdot 3 \\
2 \cdot 0\end{array}$ & $\begin{array}{l}17 \cdot 1 \\
16 \cdot 3 \\
28 \cdot 7\end{array}$ & $\begin{array}{l}1 \cdot 0 \\
1 \cdot 0 \\
1 \cdot 5\end{array}$ \\
\hline 3 & $26 \cdot 6$ & $\begin{array}{r}0 \cdot 0 \\
16 \cdot 8 \\
23 \cdot 3 \\
30 \cdot 0 \\
40 \cdot 5 \\
45 \cdot 7\end{array}$ & $\begin{array}{l}112 \\
111 \\
111 \\
114 \\
130 \\
144\end{array}$ & $\begin{array}{l}3 \cdot 4 \\
3 \cdot 4 \\
4 \cdot 2 \\
3 \cdot 6 \\
3 \cdot 8 \\
4 \cdot 4\end{array}$ & $\begin{array}{l}3 \cdot 1 \\
2 \cdot 9 \\
1 \cdot 4\end{array}$ & $\begin{array}{l}0 \cdot 6 \\
2 \cdot 9 \\
6 \cdot 2\end{array}$ \\
\hline 33 & 31.4 & $\begin{array}{r}0 \cdot 0 \\
1 \cdot 4 \\
17 \cdot 9 \\
37 \cdot 2 \\
49 \cdot 0\end{array}$ & $\begin{array}{l}102 \\
101 \\
100 \\
111 \\
137\end{array}$ & $\begin{array}{l}5 \cdot 1 \\
4 \cdot 0 \\
3 \cdot 0 \\
3 \cdot 0 \\
4 \cdot 9\end{array}$ & $\begin{array}{l}0 \cdot 8 \\
1 \cdot 2 \\
0 \cdot 8\end{array}$ & $\begin{array}{l}0.05 \\
0 \cdot 11 \\
1 \cdot 0\end{array}$ \\
\hline
\end{tabular}

reserve has been exhausted. It then rises in a manner identical to that observed in toads with no fluid reserves in the bladder. Thus the water deficit at the inflection point of the curve for each toad approximates the volume of sodium-free water derived from the bladder contents-the "apparent water reserve"-and this reserve is very close to the estimated volume of urine present when dehydration was begun. 


\section{DISCUSSION}

If osmotic equilibrium is maintained between a toad's major fluid compartments and the animal has no means of altering its solute content or gaining water, evaporation should increase the osmotic concentration in any fluid compartment by an amount commensurate with the fraction of the total water content lost by the toad. Thus in a dehydrated toad the concentration $(C)$ of any body fluid should be related to the original concentration of that fluid $\left(C_{0}\right)$, the water content of the hydrated toad $(\mathrm{ml} / 100 \mathrm{~g})$, and the water deficit $(\mathrm{ml} \mathrm{lost} / 100 \mathrm{~g})$ as follows:

$$
C=C_{0} \times \frac{\text { original water content }}{\text { original water content }- \text { water deficit }} \text {. }
$$

From this it follows that:

$$
1-\frac{C_{0}}{C}=\frac{\text { water deficit }(\mathrm{ml} / 100 \mathrm{~g})}{\text { original water content } \mathrm{ml} / 100 \mathrm{~g})} .
$$

This relationship was tested for plasma using the sodium concentration as an index of the total osmotic potential. When $1-\left(\mathrm{Na}_{0} / \mathrm{Na}\right)$ is plotted against water deficit using plasma concentrations obtained from toads dehydrated without the benefit of bladder reserves, a straight line is obtained (Fig. 3). The reciprocal of the slope, which should equal the water content of hydrated toads according to the above equation, is $79.4 \mathrm{ml} / 100 \mathrm{~g}$. This is consistent with the value of $78 \mathrm{ml} / 100 \mathrm{~g}$ determined by drying hydrated toads to constant weight at $105^{\circ} \mathrm{C}$ (see Table 2). The sum of the sodium and potassium concentrations in tissue water increases in dehydrated toads according to the same relationship, as does the concentration of chloride in both plasma and tissue water. It thus appears that these toads cannot modify the direct relation between the concentration of their body fluids and the extent of their evaporative water loss. As far as can be judged from comparison of the total cation concentrations in tissue water and plasma, osmotic equilibrium appears to be maintained between the cells and the extracellular fluid during dehydration.

Potassium constitutes only a small fraction of the osmotically active material in the extracellular fluid, although it is abundant intracellularly, and its concentration in the plasma might not be expected to follow the same pattern as sodium. The pronounced decrease in the concentration of potassium in the plasma of moderately dehydrated toads indicates that this cation is removed from the extracellular compartment during the initial stages of dehydration. 'The subsequent rise in the concentration of potassium in the plasma, occurring when the water deficit exceeds about $15 \mathrm{ml} / 100 \mathrm{~g}$, is probably due to the concentrating effect of water loss.

The fraction of the original water content lost by each tissue as a result of dehydration should equal the fraction of the total body water lost by the toad if water losses were uniformly distributed throughout the animal. Data in Table 2 show that this is not the case, water being retained by the tissues at the expense of other body fluids. Moreover, comparison of the ionic contents of muscle and liver in hydrated and dehydrated toads (Table 3 ) reveals that dehydration results in a 
net uptake of ions by these tissues. The combined sodium and potassium content of skeletal muscle increased 49 m-equiv. $/ \mathrm{kg}$ dry weight. The sum of sodium and potassium concentrations in the plasma, which approximates that for the extracellular fluid in general, was $159 \mathrm{~m}$-equiv./1. Thus the increased ionic content of muscle could account for the observed retention of water by this tissue since:

$$
\frac{49 \mathrm{~m} \text {-equiv. } / \mathrm{kg} \text { dry weight }}{159 \mathrm{~m} \text {-equiv. } / \mathrm{l}}=0.31 \mathrm{l} / \mathrm{kg} \text { dry weight. }
$$

The volume of water actually retained by muscle in excess of that expected if water losses had been uniformly distributed was $0.271 . / \mathrm{kg}$ dry weight. Similar calculations for liver yield values of 0.26 and $0.331 . / \mathrm{kg}$ dry weight for the observed excess water retention and that predicted from the net ionic uptake respectively. The calculation based on ionic uptake is an approximation, since only cations are considered. However, it is adequate to demonstrate that the uptake of solutes by the tissues is commensurate with their retention of water during dehydration. The ability of a tissue to retain water and take up ions apparently depends on its solid component since the excess water retention per unit dry weight is about the same for all tissues examined (see Table 2).

Chloride appears restricted primarily to the extracellular compartment of skeletal muscle of hydrated frogs (Conway, 1957). The "chloride space" of muscle from hydrated and dehydrated toads, calculated from data in Tables 2 and 3 , is 19.6 and $21.0 \mathrm{ml} / \mathrm{kg}$ wet weight respectively. On this basis it appears that the cellular compartment of muscle suffers disproportionately large losses of water during dehydration. Similar observations on rats led Dicker (1949) to conclude that the extracellular fluid volume is maintained during dehydration at the expense of the cells. However, it is by no means certain that there is no net gain of chloride by the cells during dehydration, so that chloride space may not be a reliable index of extracellular fluid volume under these conditions. Studies of the effects of dehydration on the volumes of the major fluid compartments of Bufo marinus show that cellular fluid volume is maintained at the expense of extracellular fluid (Shoemaker, 1963). Also, the initial decrease in the concentration of potassium in the plasma during dehydration indicates that this cation is removed from the extracellular compartment. Moreover, the increase in potassium content of muscle and liver relative to their increase in sodium is much greater than the ratio of potassium to sodium in extracellular fluid. In view of these facts, it seems likely that electrolytes are taken up by the cells during dehydration, and this uptake permits the maintenance of the fluid volume of the cells while satisfying the conditions of osmotic equilibrium.

The concentration of sodium in the plasma of amphibians is considerably lower than in other terrestrial and freshwater vertebrates; i.e. 100-120 m-equiv./ 1 as compared to $140-160$ m-equiv./1 in mammals, birds, reptiles and fresh-water fishes (Prosser \& Brown, 1961). Also, the total water content of hydrated amphibians is somewhat higher than that of most other vertebrates. Thus when a toad has 
incurred a water deficit of $20 \mathrm{ml} / 100 \mathrm{~g}$ its water content $(72 \mathrm{ml} / 100 \mathrm{~g})$ and plasma sodium concentration ( $155 \mathrm{~m}$-equiv./1) are typical of values for most other vertebrates. In view of this, the ability of amphibians to withstand large water losses becomes more understandable. It is evident from Fig. 1 and Table 3 that toads can tolerate considerable elevation of the concentrations of the principle monovalent cations in their body fluids, but it is not clear whether death resulting from dehydration is due to this elevation or to other effects of fluid loss. Concentrations of sodium as high as $250 \mathrm{~m}$-equiv./1 have been reported in the plasma of Rana cancrivora adapted to 80 per cent sea water (Gordon et al., 1961), and similar concentrations are found in Bufo viridis adapted to brackish water (Gordon, 1962; Tercafs \& Schoffeniels, 1962).

Urine stored in the bladder provides a source of water which is utilized by toads to maintain the concentration of their body fluids at the hydrated level despite evaporative water loss. The urine of hydrated toads is sufficiently dilute so that most of the water may be resorbed passively across the bladder wall. In addition, sodium must also be resorbed since its concentration in the urine does not approach the plasma level, and may decrease, even when most of the urine has been resorbed (Table 4). This is not surprising since in vitro studies have shown that sodium may be transported out of the toad bladder against considerable concentration gradient (Leaf, 1962). Elevation of the concentration of potassium in the urine as this fluid is resorbed (Table 4) could be due to lack of resorption of this ion, potassium excretion via the kidneys, or both. In any event, so little potassium is present in the urine that its resorption is of little consequence to the utilization of this fluid.

These results conclusively affirm the assertion of Ruibal (1962) that resorption of water from the bladder may be of considerable adaptive value in the terrestrial survival of some amphibians. Ruibal measured the concentration (freezing point depression) of lymph from toads (Bufo cognatus) at various times after their removal from water and found a much less pronounced increase in this concentration in individuals possessing bladder reserves. The bladder capacity of toads is large. Ruibal (1962) observed individuals of Bufo cognatus to retain as much as $40 \mathrm{ml}$ of urine/100 g standard weight. Representatives of Bufo marinus rarely, if ever, retain this volume voluntarily in the laboratory, but they commonly retain $25 \mathrm{ml} / 100 \mathrm{~g}$ and seldom possess less than $10 \mathrm{ml} / 100 \mathrm{~g}$ standard weight when they have been left undisturbed in water. Since toads can store and resorb a volume of water nearly equal to the maximum water loss tolerated by individuals possessing no bladder reserves ( $c a .30-35 \mathrm{ml} / 100 \mathrm{~g}$ ), this ability could almost double the survival time of these animals when water is unavailable. The ability to resorb urine from the bladder is probably also important in permitting the reclamation of water excreted after water has become unavailable. A number of investigators (Ewer, 1952; Sawyer \& Schisgall, 1956; Bentley; 1958; Sawyer, 1960) have demonstrated that the resorption of water from the bladder contents is controlled through the action of neurohypophyseal hormones similar to mammalian antidiuretic hormones. 


\section{SUMMARY}

In the absence of stored urine, toads have no means of altering the elevation of body fluid concentrations that would inevitably result from evaporative water loss if solutes were not excreted. However, the effects of evaporation tend to be minimized because of the high water content and low concentrations of body fluids typical of hydrated individuals. The water content of tissues is maintained to some extent during dehydration at the expense of other body fluids. This retention of water is accompanied by a net uptake of electrolytes by the tissues. Furthermore, dilute urine stored in the bladder can be utilized to maintain the concentration of sodium in the plasma at the normal level until water losses equivalent to the volume of urine initially present in the bladder have occurred.

\section{REFERENCES}

BENTLEY P. J. (1958) The effects of neurohypophyseal extracts on water transfer across the wall of the isolated urinary bladder of the toad Bufo marinus. F. Endocrin. 17, 201-209.

CoNway E. J. (1957) Nature and significance of concentration relations of potassium and sodium ions in skeletal muscle. Physiol. Rev. 37, 84-132.

DICKER S. E. (1949) Changes in extracellular and intracellular fluid phases of muscles during starvation and dehydration in adult rats. Biochem. F. 44, 274-281.

EWER R. F. (1952) The effect of pituitrin on fluid distribution in Bufo regularis (Reuss). 7. Exp. Biol. 29, 173-177.

GoRDON M. S. (1962) Osmotic regulation in the green toad (Bufo viridis). F. Exp. Biol. 39, 167-177.

GoRdon M. S., Schmidt-Nielsen K. \& Kelly H. M. (1961) Osmotic regulation in the crab-eating frog (Rana cancrivora). F. Exp. Biol. 38, 659-678.

LEAF A. (1962) Action of neurohypophyseal hormones on the toad bladder. Gen. Comp. Endocrin. 2, 148-160.

Prosser C. L. \& Brown F. A. Jr. (1961) Comparative Animal Physiology. Saunders, Philadelphia.

Ruibal R. (1962) The adaptive value of bladder water in the toad, Bufo cognatus. Physiol. Zoöl. 35, 218-223.

SAWYER W. H. (1960) Increased permeability of the bullfrog (Rana catesbiana) bladder in vitro in response to synthetic oxytocin and arginine vasotocin and to neurohypophyseal extracts from non-mammalian vertebrates. Endocrinology 66, 112-120.

Sawyer W. H. \& Schisgall R. M. (1956) Increased permeability of the frog bladder in response to dehydration and neurohypophyseal extracts. Amer. F. Physiol. 187, 312-314.

Shoemaker V. H. (1963) Effects of dehydration on fluid distribution in Bufo marinus. Amer. Zool. 3, 529.

Tercafs R. R. \& Schoffeniels E. (1962) Adaptation of amphibians to salt water. Life Sciences 1, 19-24.

Thorson T. B. \& Svhila A. (1943) Correlation of the habits of amphibians with their ability to survive the loss of body water. Ecology 24, 374-381. 